\author{
МЕХАНІЗМ РЕАЛІЗАЦІЇ ЕЛЕКТРОННОГО УРЯДУВАННЯ \\ В МІСЦЕВИХ ГРОМАДАХ УКРАЇНИ НА ПРИНЦИПАХ ЄС
}

\title{
THE MECHANISM OF IMPLEMENTATION OF ELECTRONIC GOVERNANCE IN LOCAL COMMUNITIES OF UKRAINE ON EU PRINCIPLES
}

Удк 338.2:352:351.851

https://doi.org/10.32843/infrastruct38-66

\section{Новикова І.В.}

к.е.н., старший викладач кафредри

економіки та управління

Шосткинський інститут

Сумського державного університету

Пригара I.O.

к.е.н., старший викладач кафедри

економіки та управління

Шосткинський інститут

Сумського державного університету

Typ O.M.

к.е.н., завідувач касредри

економіки та управління

Шосткинський інститут

Сумського державного університету у статті проведено дослідження механізму електронного урядування в місцевих громадах України в умовах євроінтеграції. Проведено дослідження існуючих рішень, таких як «Prozorro», «E-data», «Відкритий бюджет», «iGov», «Єдиний державний портал відкритих даних», «Доступ до правди», «ЄӘина система місцевих петицій» та інші місцеві ініціативи. Упровадження зазначених рішень стримується низьким фрінансово-економічним та людським потенціалом території, низьким рівнем інфоормаційної освіти жителів території, важким доступом до мережі Інтернет тощо. Задля вирішення виділених у ході дослідження проблем запропоновано вдосконалити існуючий механізм реалізації електронної демократії під час управління територіальною громадою. У рамках даного механізму взаємодія державних органів влади та суб'єктів територіальної громади під час реалізації електронної демократії має бути основана на справедливому перерозподілі виробничих та природних ресурсів й обмеженні окремих параметрів господарської діяльності суб'єктів територіальної громади з метою дотримання соціально-економічних законів. Незважаючи на вагомі досягнення у ссрері електронного урядування на місиях, в Україні необхідно вдосконалювати дієві механізми та інструменти фоормування співпраці громадян та державних органів влади на принципах Європейського Союзу. Ключові слова: електронне урядування, е-демократія, інфрормаційно-комунікаційні технології, механізм реалізації електронної демократії, місцева громада.

В статье проведено исследование механизма электронного управления в местных общинах Украины в условиях евроинтеграции. Проведено исследование существующих решений, таких как «Prozorro», «E-data», «Открытый бюджет», «іGov», «Единый государственный портал открытых данных», «Доступ к правде», «Единая система местных петиций» и другие местные ини циативы. Внедрение указанных решений сдерживается низким фринансово-экономическим и человеческим потенциалом территорий, низким уровнем инфрормационной образования жителей территории, трудным доступом к сети Интернет и тому подобное. Для решения выделенных в ходе исследования проблем предложено усовершенствовать существующий механизм реализации электронной демократии при управлении территориальной общиной. В рамках данного механизма взаимодействие государственных органов власти и субъектов территориальной общины при реализации электронной демократии должно быть основано на справедливом перераспределении производственных и природных ресурсов и ограничении отдельных параметров хозяйственной деятельности субъектов территориальной общины с целью соблюдения социально-экономических законов. Несмотря на значительные достижения в сфрере электронного управления на местах, в Украине необходимо совершенствовать действенные механизмы и инструменты формирования сотрудничества граждан и государственных органов власти на принципах Европейского Союза. Ключевые слова: электронное управление, э-демократия, инфрормационно-коммуникационные технологии, механизм реализации электронной демократии, местная община.

The article investigates the mechanism of e-government in local communities of Ukraine in the context of European integration. In order to identify common tendencies in the management of local communities on the principles of e-government, a study of existing solutions was conducted. It has been revealed that electronic tools such as Prozorro, E-data, Open Budget, iGov, Unified State Portal of Open Data, Access to Truth, Unified Local Petitionsand other local initiatives. The implementation of these decisions is constrained by the low financial and economic and human potential of the territory, the low level of information education of the inhabitants of the territory, the difficult access to the Internet, the low level of civic participation of the inhabitants of the territory, the reluctance of public officials to disclose information about their activities, etc. In order to solve the problems identified in the course of the research, it is proposed to improve the existing mechanism for the implementation of e-democracy in the management of the territorial community. Within the framework of this mechanism, the interaction of state authorities and territorial community entities in the implementation of e-democracy should be based on a fair redistribution of production and natural resources and the limitation of certain parameters of economic activity of territorial community entities in order to comply with socio-economic laws. The study concluded the following. Important steps have been taken in Ukraine to organize e-governance in local communities. Effective IT solutions have been created. These information technologies allow to increase the level of civic participation of the residents of the community, to ensure their participation in making management decisions regarding the development of the territorial community. Notwithstanding the significant achievements in the field of e-governance on the ground in Ukraine, it is necessary to improve the effective mechanisms and instruments of forming the cooperation of citizens and public authorities on the principles of the European Union. Key words: e-government, e-democracy, information and communication technologies, e-democracy implementation mechanism, local community.

Постановка проблеми. Управління розвитком місцевих громад, районів та областей на тлі науково-технічного прогресу неможливо уявити без інфрормаційних технологій. Саме інфрормаційнокомунікаційні технології $€$ основою не тільки для соціально-економічного розвитку, а й для забезпе- 
чення ефрективного управління місцевими громадами, містами, районами чи областями країни.

Питання організації електронного урядування в місцевих органах влади України в умовах євроінтеграції суттєво актуалізувалися. Зокрема, дослідження механізмів управління міським і регіональним господарством за допомогою інформаційних технологій в Україні в умовах євроінтеграції може виявитися корисним для вирішення питань активізації поширення інформаційно-комунікаційних технологій у публічній сорері України для досягнення соціально-економічного розвитку місцевих громад.

Аналіз останніх досліджень і публікацій. Науково-методичні підходи до фрормування та реалізації механізму електронного урядування в місцевих громадах отримали свій розвиток у наукових роботах І. Кажоки [1], Л. Ковшун [2; 3], В. Некрасова [4], В. Таран [5], Б. Тишкевич [6] та ін. Проте залишаються недостатньо розкритими питання формування дієвого механізму електронного урядування в місцевих громадах, який би враховував потреби розвитку громади та громадян в умовах євроінтеграційного курсу України.

Постановка завдання. Метою статті є дослідження інструментів та механізму електронного урядування в місцевих громадах України в умовах євроінтеграції. Завданнями статті є:

- дослідження тенденцій розвитку інорормаційних технологій у місцевих громадах України;

- вивчення існуючого механізму електронного урядування в місцевих громадах та його вдосконалення з урахуванням потреб розвитку громади та громадян в умовах євроінтеграційного курсу України.

Виклад основного матеріалу дослідження. Забезпечення соціально-економічного розвитку місцевих громад багато в чому залежить від ефективних управлінських дій місцевих органів влади. Зокрема, важливо забезпечити реалізацію найважливіших потреб жителів місцевої громади. Для вирішення такого завдання все частіше застосовують інфрормаційно-комунікаційні технології управління.

Здійснимо короткий огляд існуючих рішень у реалізації електронного урядування в місцевих громадах України.

Для подолання корупції в органах влади всіх ієрархічних рівнів в Україні та забезпечення розвитку співпраці влади і громади на засадах ЄС були запроваджені такі електронні інструменти, як «Prozorro», «E-data», «Відкритий бюджет», «iGov», «Єдиний державний портал відкритих даних», «Доступ до правди», «Єдина система місцевих петицій» та інші місцеві ініціативи [5; 6].

Система «Prozorro» [6] дає змогу організувати та здійснити прозорі державні закупівлі, а також виключити чинник корупції під час їх проведення. Станом на кінець 2019 р. середньорічні обсяги державних закупівель в Україні, що були проведені через систему «Prozorro», становили близько 250 млрд грн.

Після підписання Закону України «Про відкритість використання публічних коштів» на замовлення уряду країни громадськими експертами було розроблено портал «E-data» [5; 6]. Даний портал у режимі онлайн дає змогу слідкувати за витратами бюджетних коштів національного та місцевих бюджетів. Інструменти порталу дають змогу зробити пошук необхідної інфрормації за транзакціями та розпорядниками.

Аналіз витрат та доходів бюджету, візуалізація бюджетної інфрормації стали можливими завдяки порталу «Відкритий бюджет». Інфрормація про бюджет того чи іншого міста фрормується на базі даних порталу «Е-data». Портал «Відкритий бюджет» [6] надає актуальну інорормацію про бюджетний процес у місті в зрозумілому вигляді для жителів місцевої громади. Окрім даного проєкту, є низка альтернативних ініціатив таких міст України, як Київ, Кривий Ріг, Ніжин тощо.

Портал державних послуг «iGov» $[5 ; 6]$ являє собою платформу, на якій зібрані всі адміністративні послуги, що надають державні органи влади України громадянам та юридичним особам. Нині кількість послуг налічує більше 200. Частина таких послуг провадиться онлайн через мережу Інтернет. Ідея порталу полягає у переведенні максимальної кількості адміністративних послуг у режим онлайн, що дасть змогу ефективно боротися з корупцією в державних органах влади.

На вимогу Закону України «Про доступ до публічної інформації» було створено портали «Доступ до правди» [6] та «Єдиний державний портал відкритих даних» [6]. Обидва портали допомагають громадянам отримати необхідну публічну інфрормацію про роботу державних органів влади України, у тому числі й місцевих. Так, портал «Доступ до правди» дає змогу автоматично сорормувати запит на отримання публічної інорормації та надіслати його розпоряднику. Набори даних державних та місцевих органів влади публікуються на «Єдиному державному порталі відкритих даних». Даний портал дає змогу відшукати необхідну інфрормацію за назвою, розпорядником, а також набором даних.

Для полегшення та прискорення роботи з петиціями громадян було створено «Єдину систему місцевих петицій» [5; 6]. Електронні петиції дають змогу в режимі онлайн забезпечити збір підписів серед громадян. Також даний портал дає можливість здійснювати необхідні налаштування під вимоги місцевих органів влади.

Як показує аналіз існуючих рішень у реалізації електронного урядування в місцевих громадах, їх упровадження носить радше декларативний характер. Так, більшість інфрормаційних порталів 
не отримує ні державної підтримки, ні підтримки 3 боку громадян.

Опір у впровадженні інструментів електронного урядування виникає через низку чинників соціальноекономічного та політичного характеру, зокрема:

- низький фрінансово-економічний та людський потенціал території призводить до збитковості більшості ініціатив під час упровадження інструментів електронного урядування. За такої ситуації не має можливості підтримувати роботу інструментів електронного урядування, по-перше, через брак фрінансових ресурсів, по-друге, через відсутність інтересу жителів території (громади, міста, регіону тощо) до використання згаданих інструментів;

- низький рівень інформаційної освіти жителів території. Зокрема, така проблема характерна для сільського населення, де переважно проживають громадяни віком від 60 років та старше. Сільські громади не в змозі використовувати інфрормаційно-комунікаційні технології через опір старшого покоління під час використання новітніх технологій та небажання їх освоювати;

- важкий доступ до мережі Інтернет, особливо в територіальних громадах, що охоплюють сільську місцевість. Покриття 3G-Інтернету у сільській місцевості України досі залишається незадовільним, лише великі міста країни мають якісний доступ до 3G/4G. Така обставина викликана проблемами перерозподілу радіочастот між мобільними операторами України та економічною недоцільністю суцільного покриття території країни 3G/4GІнтернетом [4];

- небажання влади впроваджувати інструменти електронного урядування через високий рівень корупції. Як видно з приведеного вище матеріалу, застосування інформаційно-комунікаційних технологій дає змогу зробити прозорим виконання будьяких дій чиновників, що керують місцевою громадою, та робить державну інфрормацію відкритою і легкодоступною для широкого загалу;

- громадянська участь у вирішенні питань розвитку громади є низькою. Участь громади у вирішенні питань розвитку та управління територією переважно зводиться до інфрормування громадян про проєкти та заходи, що плануються проводити місцевими органами влади, тому інформаційні технології радше сприймаються як інструмент пошуку інформації про те, що відбувається в територіальній громаді та які розпорядження чи накази були оприлюднені.

Остання причина низької активності населення громади в електронній демократії пов'язана не тільки 3 політичною інертністю жителів громади, а й бажанням чиновників приховати інформацію від населення громади. Розроблення дієвого механізму залучення громади до вирішення питань розвитку території 3 урахуванням євроінтеграційних тенденцій [1-3] дасть змогу поліпшити не тільки соціально-економічний стан території, а й підвищити відповідальність чиновників за свої дії.

Інструменти електронної демократії покликані забезпечити громадянську участь у прийнятті управлінських рішень [2; 3], зокрема рішень щодо бюджетного процесу, розроблення заходів із поліпшення соціально-економічного становища територіальної громади, здійснювати громадський контроль над діяльністю державних органів влади тощо.

Виходячи з вищевикладеного, можна представити механізм електронного урядування в Україні (рис. 1), який буде враховувати основні принципи електронної демократії, які $є$ базовими для європейських країн.

Отже, система реалізації електронної демократії під час управління територіальною громадою спрямована на становлення демократичних цінностей у громаді. Взаємодія державних органів влади та суб'єктів територіальної громади в рамках цієї системи управління передусім повинна бути спрямована на реалізацію цілей громади та їі жителів. Електронне урядування може стати основою для запобігання корупції, підвищення ефективності державної влади на місцях, забезпечення довгострокового економічного зростання.

Механізм реалізації електронної демократії переважно зводиться до регулювання державою матеріальних, інформаційних та фрінансових потоків між усіма суб'єктами територіальної громади. IKT є в такому разі дієвим інструментом перерозподілу ресурсів громади на справедливій основі 3 дотриманням законів України. Перерозподіл фрінансових, матеріальних та трудових ресурсів здійснюється на користь пріоритетних напрямів розвитку громади, що визначені громадянами такої громади. Будь-які дії владних органів місцевої громади спрямовані на забезпечення захисту соціально-економічних інтересів громади, економічних регіонів, суб'єктів підприємницької діяльності та споживачів, що здійснюється шляхом застосування певної сукупності інструментів.

Державні органи влади повинні застосовувати таку сукупність стимулів стосовно суб'єктів територіальної громади, які б робили залучення і використання ресурсів громади економічно вигідним. Механізм електронної демократії в місцевих громадах реалізується через безпосередню участь держави шляхом застосування до суб'єктів територіальної громади визначеного комплексу еколого-економічних інструментів впливу на їхні ключові інтереси.

Взаємодія державних органів влади та суб'єктів територіальної громади в рамках механізму реалізації електронної демократії передусім повинна бути спрямована на перерозподіл виробничих та природних ресурсів і обмеження окремих параметрів господарської діяльності суб'єктів територіальної громади $з$ метою дотримання соціально-економічних 


\begin{tabular}{|c|c|}
\hline \multicolumn{2}{|c|}{ Суб'єкти управління територіальною громадою з використанням інструментів е-демократії } \\
\hline $\begin{array}{c}\text { Голова територіальної } \\
\text { громади }\end{array}$ & Заступники голови та працівники державного орану управління \\
територіальною громадою
\end{tabular}

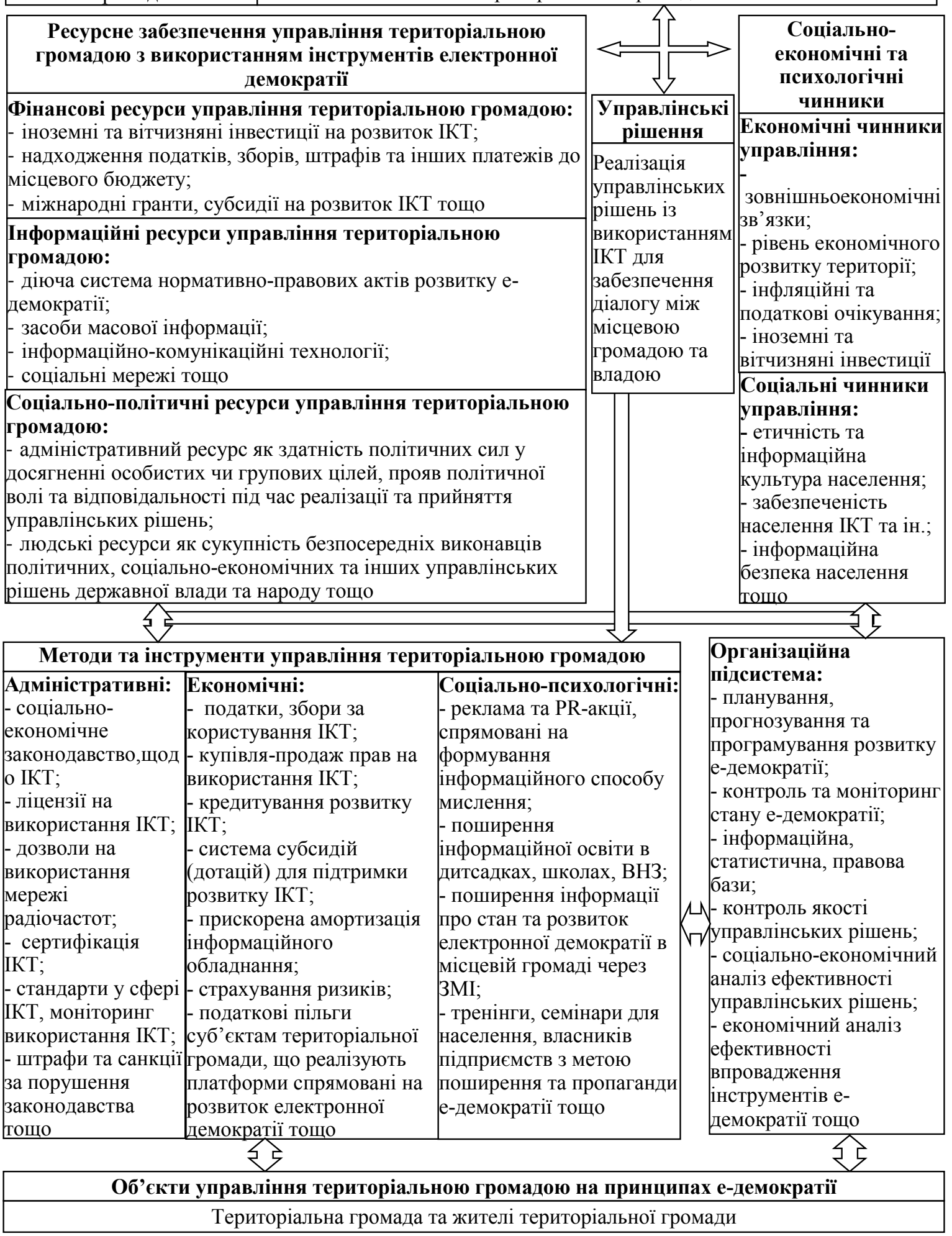

Рис. 1. Механізм реалізації електронної демократії при управлінні територіальною громадою

законів. Виконання зазначених завдань можливе шляхом застосування певної сукупності інструментів адміністративного чи ринкового регулювання господарської діяльності. Приведений на рис. 1 механізм спрямований на фрормування тісної співпраці між державними органами влади та суб'єктами територіальної громади з використанням IKT на принципах е-демократії європейських країн [1-3]. 
Висновки 3 проведеного дослідження. В Україні здійснено немало важливих заходів для організації електронного урядування в місцевих громадах. Створено низку ефективних рішень із використанням інфрормаційних технологій, що дають змогу отримати доступ до публічної інфрормації та низки адміністративних послуг онлайн. Незважаючи на вагомі досягнення у сфері електронного урядування на місцях, в Україні слід впроваджувати дієві механізми та інструменти фрормування співпраці громадян та державних органів влади, адже завдяки такій співпраці фоормється найвища форма залученості громади до прийняття управлінських рішень по розвитку територіальних громад України, за якої думка та бажання жителів громади ставляться на перше місце.

На нашу думку, подальших наукових розвідок потребують такі питання:

- удосконалення механізму залучення громадян до прийняття управлінських рішень розвитку місцевої громади з урахуванням євроінтеграційних процесів;

- визначення науково-методичних підходів до державного фрінансування розвитку електронного урядування в Україні.

\section{БІБЛІОГРАФІЧНИЙ СПИСОК:}

1. Кажока І. Електронна демократія: 10 практик 3 Європи. Mistosite. 2016. 9 червня. URL: https://mistosite. org.ua/articles/elektronna-demokratiia-10-praktyk-zyevropy?locale=ru (дата звернення: 18.12.2019).

2. Ковшун Л. Рівні співпраці влади і громади: шість типологій громадянської участі. Mistosite. 2016. 17 березня. URL: https://mistosite.org.ua/uk/articles/ r\%D1\%96vn\%D1\%96-sp\%D1\%96vpracz\%D1\%96vlady-\%D1\%96-gromady-sh\%D1\%96st-typolog\% D1\%96j-gromadyanskoyi-uchast\%D1\%96 (дата звернення: 18.12.2019).

3. Ковшун Л. Як оцінювати громадянську участь: шість інструментів. Mistosite. 2016. 14 січня. URL: https://mistosite.org.ua/ru/articles/yak-otsiniuvatyhromadiansku-uchast-shist-instrumentiv (дата звернення: 18.12.2019).

4. Некрасов В. 4G не поможет: почему в Украине нет сплошного 3G-покрытия и как это справить. Экономическаяправда. 2018.15марта. URL:https://www. epravda.com.ua/rus/publications/2018/03/15/634981/ (дата звернення: 18.12.2019).
5. Таран В. ТОП-5 електронних ініціатив, які змінять Україну. Дзеркало тижня. 2016. № 7. URL: https:// dt.ua/internal/top-5-elektronnih-iniciativ-yaki-zminyatukrayinu-_.html (дата звернення: 18.12.2019).

6. Тишкевич Б. Електронна демократія: 11 практик з України. Mistosite. 2017. 5 серпня. URL: https:// mistosite.org.ua/ru/articles/elektronna-demokratiia-11praktyk-z-ukrainy (дата звернення: 18.12.2019).

\section{REFERENCES:}

1. Kazhoka I. (2016) Elektronna demokratiya: 10 praktik z Yevropi [Electronic Democracy: 10 Practices from Europe]. Mistosite (electronic journal), 09.06.2016. Available at: https://mistosite.org.ua/articles/elektronnademokratiia-10-praktyk-z-yevropy?locale=ru (accessed 18 December 2019).

2. Kovshun L. (2016) Rivni spivpraci vladi i gromadi: shist tipologij gromadyanskoyi uchasti [Level of cooperation between power and community: six types of public participation]. Mistosite (electronic journal), 17.03.2016. Available at: https://mistosite.org.ua/ uk/articles/r\%D1\%96vn\%D1\%96-sp\%D1\%96vpracz\% D1\%96-vlady-\%D1\%96-gromady-sh\%D1\%96sttypolog\%D1\%96j-gromadyanskoyi-uchast\%D1\%96 (accessed 18 December 2019).

3. Kovshun L. (2016) Yak ocinyuvati gromadyansku uchast: shist instrumentiv [How to evaluate public participation: six tools]. Mistosite, 14.01.2016. Available at: https://mistosite.org.ua/ru/articles/yak-otsiniuvatyhromadiansku-uchast-shist-instrumentiv (accessed 18 December 2019).

4. Nekrasov V. (2018) 4G ne pomozhet: pochemu $\checkmark$ Ukraine net sploshnogo 3G-pokrytiya i kak eto ispravit [4G does not help: why in Ukraine there is no solid $3 G$ cover and how to fix it]. Ekonomicheskaya pravda [Economic truth], 15.03.2018. Available at: https://www. epravda.com.ua/rus/publications/2018/03/15/634981/ (accessed 18 December 2019).

5. Taran V. (2016) TOP-5 elektronnih iniciativ, yaki zminyat Ukrayinu [Top], 5 electronic initiatives that will change Ukraine]. Dzerkalo tizhnya [Mirror of the week], no. 7. Available at: https://dt.ua/internal/top-5-elektronnih-iniciativ-yaki-zminyat-ukrayinu-_.html (accessed 18 December 2019).

6. Tishkevich B. (2017) Elektronna demokratiya: 11 praktik z Ukrayini [Electronic Democracy: 11 Practices from Ukraine]. Mistosite, 05.08.2017. Available at: https://mistosite.org.ua/ru/articles/elektronna-demokratiia-11-praktyk-z-ukrainy (accessed 18 December 2019). 
Novikova Inna

Candidate of Economic Sciences,

Senior Instructor of Economics and Management Department

Shostka Institute

Sumy State University

Prigara Irina

Candidate of Economic Sciences,

Senior Instructor of Economics and Management Department

Shostka Institute

Sumy State University

Tur Aleksandr

Candidate of Economic Sciences, Head of Economics and Management Department

Shostka Institute

Sumy State University

\section{THE MECHANISM OF IMPLEMENTATION OF ELECTRONIC GOVERNANCE IN LOCAL COMMUNITIES OF UKRAINE ON EU PRINCIPLES}

The article investigates the mechanism of e-governance in local communities of Ukraine in the context of European integration. In order to identify common trends in local community governance, e-governance has been investigated into existing solutions.

It is revealed that the following electronic tools have been introduced in Ukraine to prevent corruption in local authorities: Prozorro, a website for government procurement and tendering; «E-data» - this site allows to monitor the spending of national and local budgets; "Open budget" - this decision allows to analyze the expenditures and revenues of the budget, visualize budget information; «iGov» - is a platform on which all administrative services provided by the state authorities of Ukraine to citizens and legal entities are gathered; "Single State Open Data Portal" and "Access to Truth" - portals that allow citizens to access necessary public information about the work of state authorities of Ukraine, including local ones; "Unified system of local petitions" - this solution was created to facilitate and speed up the work with citizens' petitions.

The implementation of these decisions is constrained by: low financial, economic and human potential of the territory, which leads to the loss of most e-democracy initiatives; low level of information education of the inhabitants of the territory, which leads to low activity of the community residents in the implementation of e-democracy tools; difficult access to the Internet, especially in rural communities, which minimizes the socio-economic effects of implementing e-democracy tools in rural areas; low level of civic participation of the inhabitants of the territory, which leads to the perception of e-democracy tools as a source of information on the work of state authorities; the reluctance of public servants to disclose information about their activities, which leads to corruption and the closure of public information, etc.

In order to solve the problems identified in the course of the research, it is proposed to improve the existing mechanism for the implementation of e-democracy in the management of the territorial community. This mechanism basically boils down to state regulation of material, information and financial flows between all subjects of the territorial community. In this case, information and communication technologies are an effective tool for redistributing community resources on a fair basis, in compliance with the laws of Ukraine. Redistribution of financial, material and labor resources is carried out in favor of priority directions of community development. Any action by local government authorities is aimed at protecting the socio-economic interests of the community, economic regions, business entities and consumers through the use of a set of tools.

The mechanism of e-democracy in local communities is realized through the direct involvement of the state by applying to the territorial community entities a certain set of environmental and economic instruments to influence their key interests.

The interaction of state authorities and territorial community entities within the framework of the e-democracy implementation mechanism should primarily aim at redistributing production and natural resources and limiting certain parameters of economic activity of territorial community entities in order to comply with socioeconomic laws. The fulfillment of these tasks is possible by applying a certain set of instruments of administrative or market regulation of economic activity.

The study concluded the following. Important steps have been taken in Ukraine to organize e-governance in local communities. Effective IT solutions have been created. These information technologies allow to increase the level of civic participation of the residents of the community, to ensure their participation in making management decisions regarding the development of the territorial community. Notwithstanding the significant achievements in the field of e-governance on the ground in Ukraine, it is necessary to improve the effective mechanisms and instruments of forming the cooperation of citizens and public authorities on the principles of the European Union. 